\title{
Induction of apoptosis in HeLa cells by trans-activation-deficient p53
}

\author{
Ygal Haupt, ${ }^{1}$ Sheldon Rowan, ${ }^{1}$ Eitan Shaulian, ${ }^{1}$ Karen H. Vousden, ${ }^{2,3}$ and Moshe Oren ${ }^{1,4}$ \\ ${ }^{1}$ Department of Chemical Immunology, The Weizmann Institute of Science, Rehovot 76100 , Israel; ${ }^{2}$ Ludwig Institute for \\ Cancer Research, St. Mary's Hospital Medical School, London W2 1PG, UK
}

The p53 tumor suppressor protein is a transcriptional activator, which can mediate apoptotic cell death in a variety of cell types. To determine whether sequence-specific trans-activation is a prerequisite for the induction of apoptosis by p53, the apoptotic effects of various p53 deletion mutants were monitored in an assay based on the transient transfection of HeLa cells. A truncated protein (p53d1214), containing only the first 214 amino-terminal residues of murine p53, induced extensive apoptosis, albeit at a slower rate than trans-activation-competent wild-type p53. p53dl214 also suppressed the transformation of rat fibroblasts by several oncogene combinations and particularly by myc plus ras and HPV E7 plus ras. p53d1214 lacks a major portion of the DNA-binding domain and cannot activate p53-responsive promoters. Moreover, a human p53 protein carrying mutations in residues 22 and 23 also triggered HeLa cell apoptosis, despite failing to induce significant activation of relevant p53 target promoters. These data suggest the existence of two p53-dependent apoptotic pathways-one requiring activation of specific target genes, and the other independent of sequence-specific trans-activation. The latter pathway may actually be totally uncoupled from the binding of p53 to its consensus DNA sites. The relative contribution of trans-activation-independent apoptosis to tumor suppression by 53 may be dictated by the specific genetic lesions present in the particular tumor.

[Key Words: p53; apoptosis; TUNEL; tumor suppression]

Received January 23, 1995; revised version accepted July 10, 1995.

The p53 tumor suppressor gene is a very frequent target for genetic alterations in cancer (Harris and Hollstein 1993; Friend 1994). Enhanced activity of wild-type p53 can mediate a variety of anti-proliferative effects, including the suppression of oncogene-mediated transformation, induction of a growth arrest in the $G_{1}$ phase of the cell cycle, and activation of apoptotic cell death (for review, see Oren 1992; Donehower and Bradley 1993; Levine 1993; Berns 1994; Oren 1994; Haffner and Oren 1995). The involvement of wild-type p53 in the control of apoptosis has been demonstrated in a wide array of biological systems, in vitro and in vivo /Yonish-Rouach et al. 1991; Shaw et al. 1992; Johnson et al. 1993; Lotem and Sachs 1993; Lowe et al. 1993; Ramqvist et al. 1993; Ryan et al. 1993; Wang et al. 1993; Clarke et al. 1994; Gottlieb et al. 1994; Symonds et al. 1994). p53-mediated growth arrest and apoptosis are tightly inter-related at the cellular level. In particular, members of the RB family and of the E2F transcription factor family appear to play an important role in the decision as to whether a cell will respond to wild-type p53 activation by executing a viable $G_{1}$ arrest or undergoing apoptosis (YonishRouach et al. 1993; Demers et al. 1994; Hickman et al.

\footnotetext{
${ }^{3}$ Present address: NCI-Frederick Research and Development Center, Frederick, MD 21702-1201 USA.

${ }^{4}$ Corresponding author.
}

1994; Howes et al. 1994; Morgenbesser et al. 1994; Pan and Griep 1994; Qin et al. 1994; Slebos et al. 1994; White et al. 1994; Wu and Levine 1994; Haupt et al. 1995).

At the biochemical level, p53 can engage in sequencespecific trans-activation (SST) (Vogelstein and Kinzler 1992; Prives 1994). Transcriptional activation of target genes is closely correlated with the growth-inhibitory effect of p53 (Reed et al. 1993; Shaulian et al. 1993; Crook et al. 1994; Ory et al. 1994; Pietenpol et al. 1994). At least part of this effect may be mediated through induction of the Waf1/cip1 gene, which encodes the cyclin-dependent kinase inhibitor p21 (Ei-Diery et al. 1993; Harper et al. 1993; Xiong et al. 1993; Dulic et al. 1994). Although Waf 1 expression is also induced in cells undergoing p53-mediated apoptosis (El-Deiry et al. 1994), it is not clear whether this plays any role in the apoptotic process. In at least certain cell types, high levels of Waf1 may actually inhibit apoptosis rather than promote it (Canman et al. 1995).

To investigate the relationship between SST and p53mediated apoptosis, we analyzed the ability of various p53 deletion mutants to induce apoptosis in HeLa cells. We report here that a truncated polypeptide, containing only the first 214 residues (of 390) of murine p53, can act as a potent inducer of apoptosis, despite lacking any demonstrable SST capacity. Similarly, a human p53 protein mutated at residues 22 and 23 also triggers HeLa 
cell apoptosis, despite failing to activate a reporter gene driven by relevant p53 target promoters. Although the apoptotic response to the truncated polypeptide is quite substantial, the kinetics of the process are slower than for full-length wild-type p53. These data are compatible with the existence of two distinct p53-dependent apoptotic pathways, at least in HeLa cells. One pathway appears to operate in the absence of SST, whereas the other might require the activation of particular p53 target genes. Moreover, transformation inhibition experiments suggest that trans-activation-independent apoptosis may contribute to tumor suppression by $\mathrm{p} 53$. The relative contribution of each apoptotic pathway is probably dictated by the types of deregulated signals delivered to the particular tumor cell.

\section{Results}

\section{A p53 deletion mutant, incapable of SST, induces apoptosis in HeLa cells}

Overexpression of wild-type p53 in HeLa cells induces apoptotic cell death, which can be scored in an assay based on fluorescence-activated cell sorter (FACS) analysis of transiently transfected cells (Yonish-Rouach et al. 1994; Haupt et al. 1995). We took advantage of this experimental model system in an attempt to define functional domains required for p53-mediated apoptosis. To that end, we studied the ability of several mouse p53 deletion mutants, differing in their biochemical activities, to induce apoptosis in transfected HeLa cells. The mutants employed in this study are depicted schematically in Figure 1A. Two of the mutants, p53dl330 and p53dl303, lack the oligomerization domain but retain intact DNA-binding and trans-activation domains (Friend 1994; Prives 1994). Both mutants have been shown to activate p53-responsive genes and suppress oncogene-mediated transformation (Shaulian et al. 1995). The third mutant, p53dl214, lacks a crucial portion of its DNA-binding domain and is therefore not expected to bind specifically to consensus DNA sites and activate p53 target genes. Expression of wild-type and mutant forms of murine p53 was driven by the strong cytomegalovirus (CMV) immediate-early regulatory element. The expression pattern of the corresponding polypeptides, analyzed by Western blotting $20 \mathrm{hr}$ after the transient transfection of HeLa cells, is shown in Figure 1B. It is evident that all truncated proteins were expressed at comparable levels in transfected HeLa cells and migrated in the gel at positions compatible with their expected sizes.

To assess the relevance of SST to p53-mediated apoptosis in HeLa cells, it was first essential to determine the ability of each p53 deletion mutant to activate a p53responsive promoter. HeLa cells were transiently transfected with each mutant plus a reporter plasmid containing 17 tandem copies of the ribosomal gene cluster (RGC) p53-binding site (Kern et al. 1991). To avoid reduction of luciferase activity owing to cell death, extracts were prepared $18 \mathrm{hr}$ post transfection. The results

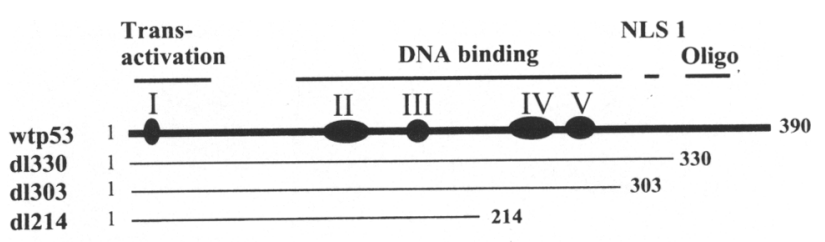

B

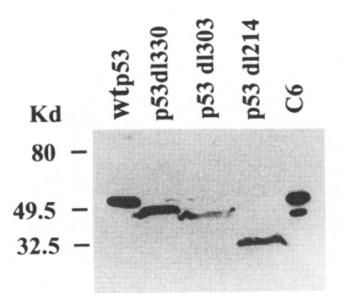

Figure 1. Mouse p53 deletion mutants employed in this study. (A) Schematic map of the mutant proteins, relative to fulllength wild-type p53. Roman numerals denote the five conserved boxes of wild-type p53 (Soussi et al. 1990). Some of the functional domains of the protein are indicated as well. (NLS-1) Major nuclear localization signal (Shaulsky et al. 1990); (Oligo) oligomerization domain (Shaulian et al. 1992; Sturzbecher et al. 1992); (DNA binding) sequence-specific binding only. (B) Expression of mouse wild-type p53 and various deletion mutants in transiently transfected HeLa cells, assayed by Western blot analysis. HeLa cells $\left(10^{6}\right.$ cells per $10-\mathrm{cm}$ dish) were transfected with $5 \mu \mathrm{g}$ of the appropriate plasmid. Cell extracts were prepared $20 \mathrm{hr}$ later. The blot was probed with PAb248. (C6) Extract prepared from clone 6 cells (Pinhasi-Kimhi et al. 1986), stably overexpressing transfected mouse p53, employed as a positive control. Positions and molecular masses of protein size markers are shown at left.

are shown in Fig. 2. A low basal activity of the reporter was seen in the presence of an empty vector control (CMV); this probably reflects the residual activity of endogenous HeLa human wild-type p53 (Hoppe-Seyler and

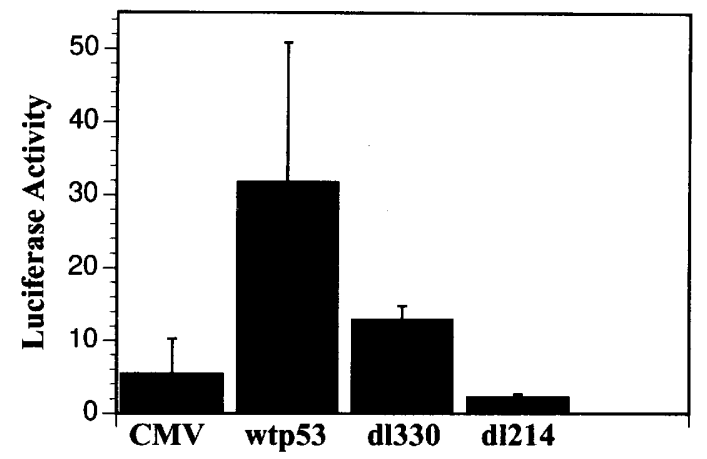

Figure 2. Transcriptional activation of a p53-dependent promoter by various mouse p53 mutants. HeLa cells $\left(5 \times 10^{5}\right.$ cells per $6-\mathrm{cm}$ dish) were transfected, by the calcium phosphate method, with $1 \mu \mathrm{g}$ of the indicated plasmid DNA plus $1 \mu \mathrm{g}$ of RGC-luciferase (Haupt et al. 1995). Luciferase activity was determined $18 \mathrm{hr}$ later and is shown in arbitrary units. Each assay was done in triplicate; the standard deviation is indicated. (CMV) Empty vector control. 


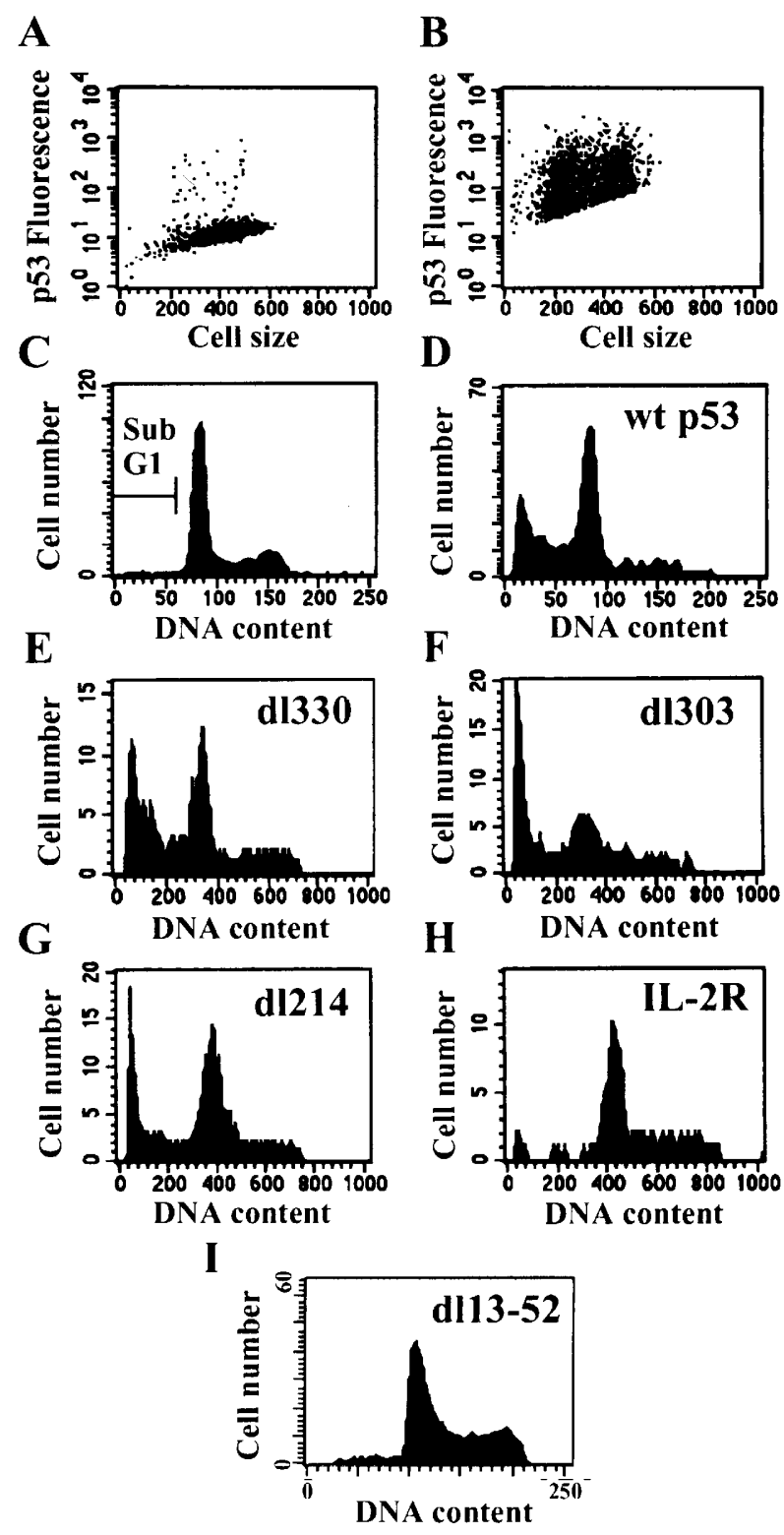

Butz 1993). A marked activation was obtained in cells transfected with the reporter plus wild-type p53. In agreement with previous data (Shaulian et al. 1995), p53dl330 also exhibited distinct transcriptional activity, albeit lower than that of wild-type p53. In contrast, p53dl214 was totally incapable of STT of this reporter.

The effect of overexpression of each protein on the cell cycle distribution of transfected HeLa cells was determined by flow cytometric analysis, using double staining. Following transfection, cells were analyzed for mouse p53 expression with the aid of the mouse p53specific monoclonal antibody PAb248. The antibody was either conjugated directly to fluorescein-5-isothiocyanate (FITC) or visualized by FITC-conjugated goat antimouse secondary antibody. Subsequently, the same cells were stained for DNA content by propidium iodide (PI). The small percentage of cells overexpressing transfected mouse p53 was identified through its high fluorescence
Figure 3. Induction of HeLa cell death by transfection with different murine p53 variants. HeLa cells $\left(10^{6}\right.$ per $10-\mathrm{cm}$ dish $)$ were transfected with $5 \mu \mathrm{g}$ of plasmid DNA encoding mouse wild-type p53 $(A-D)$ or various polypeptides as indicated in each panel $(E-H)$. Forty-eight hr post-transfection, adherent and floating cells were collected together from each transfected culture, fixed with methanol, and analyzed by flow cytometry. Cellular transfected mouse p53 content was determined by staining with the monoclonal antibody PAb248 (p53, $A$ and $B$ ) and is plotted as a function of cell size (forward scatter). DNA content was quantified by staining the fixed cells with PI. $(A)$ An unsorted aliquot of a culture transfected with wild-type p53. The DNA content distribution of the same aliquot is shown in $C$ / the horizontal bar denotes the position of cells with sub- $G_{1}$ DNA content, indicative of apoptosis) $(B)$ The analysis of the subpopulation expressing high levels of transfected mouse p53, derived by sorting a large number of cells from the culture shown in $A$ and gating for elevated p53 fluorescence; note that p53 fluorescence is plotted on a logarithmic scale. The DNA content of the same subpopulation is shown in $D$. The data for $E-I$ were derived as for $D$, except that cells were transfected with the indicated p53 deletion mutants $(E, F, G, I)$ or with an expression vector for a truncated IL-2R $(H)$. $(H)$ Staining and gating for positive transfectants were done with 7G7B6, a monoclonal antibody specific for IL-2R rather than for p53 (see Materials and methods).

intensity, which was well above that of the weakly staining bulk nonexpressor population (Fig. $3 \mathrm{~A}$; note that p53 fluorescence is plotted on a logarithmic scale). A gate was then set to include only those cells that contain high levels of mouse p53. Cells falling within this gate (Fig. 3B), presumed to represent the successfully transfected subpopulation, were collected out of a much larger total number of cells, and analyzed separately. Equal numbers of nongated (largely nontransfected) and gated (successfully transfected) cells were then compared with regard to their cell cycle distribution as defined by DNA content (Fig. 3, C and D, respectively).

Figure 3, A-D, depicts the analysis, performed $48 \mathrm{hr}$ post-transfection, of a culture transfected with fulllength mouse wild-type p53. It is evident that whereas the bulk, mostly non-transfected cell population displayed a normal cell cycle distribution (Fig. 3C), many of the cells overexpressing wild-type p53 exhibited a sub$G_{1}$ DNA content, indicative of apoptotic death (Darzynkiewicz et al. 1992; Yonish-Rouach et al. 1994; Haupt et al. 1995). Similarly, p53dl330 and p53dl303 also induced significant cell death (Fig. 3, E and F, respectively). Surprisingly, p53dl214 also was an effective inducer of cell death (Fig. 3G). By $48 \mathrm{hr}$ after transfection with a p53d1214 expression plasmid, a substantial fraction of the HeLa cells overexpressing this truncated protein exhibited a sub-G $\mathrm{G}_{1}$ DNA content. Hence, even though the p53d 214 protein is totally incapable of transactivating a p53-responsive target promoter (Fig. 2), it can nevertheless promote a vigorous death response. This finding argues that SST is not a prerequisite for the ability of p53 to induce HeLa cell death. One could pro- 
pose that the effect of $\mathrm{p} 53 \mathrm{dl} 214$ was nonspecific, resulting from the activation of the residual endogenous HeLa cell wild-type p53 by the transfected plasmid DNA through a DNA damage-induced pathway. If that were the case, the successful transient introduction of any plasmid into HeLa cells would be predicted to have a similar apoptotic effect. To test this possibility, a HeLa culture was transiently transfected with an expression plasmid encoding a truncated version of the human interleukin-2 receptor (IL-2R). Successfully transfected cells were identified with the aid of an anti-IL-2R monoclonal antibody, and gated essentially as described for mouse p53 transfectants. As seen in Figure $3 \mathrm{H}$, transfection of HeLa cells with the IL-2R plasmid failed to induce apoptosis above the spontaneous background rate. Furthermore, transfection of tumor-derived mouse p53 mutants also did not promote any apoptosis in HeLa cells (Haupt et al. 1995; see also Fig. 5, below). Similarly, no apoptotic activity was exerted by a mouse p 53 deletion mutant lacking residues $13-52$ (Fig. 3I). This strongly suggests that the induction of HeLa cell death is attributable to the biological activity of the introduced protein, rather than to an irrelevant effect of the transfection procedure.

It had been shown previously that the death induced in HeLa cells by overexpression of wild-type p53 exhibits distinct apoptotic features (Yonish-Rouach et al. 1994; Haupt et al. 1995). To test whether the same was also true for $\mathrm{p} 53 \mathrm{dl} 214$, HeLa cells were transfected with wildtype p53 or p53dl 214 and analyzed microscopically $48 \mathrm{hr}$ later (Fig. 4). Adherent as well as floating cells were collected together and fixed in methanol, essentially as done for flow cytometric analysis. This procedure allows one to analyze the entire cell population, including those cells that have already detached from the dish. Fixed cells were then doubly stained for p53 (PAb248 followed by goat anti-mouse antibodies conjugated to rhodamine) and for DNA (DAPI). Because cells were fixed in suspension, it is difficult to visualize the cytoplasm in Figure 4. Analysis of adherent cells, fixed while still attached to the coverslip, revealed a strictly nuclear staining of $\mathrm{p} 53$ following transfection with wild-type p53, and a mixed nuclear and cytoplasmic staining following transfection with p53d1214 (data not shown).

In agreement with earlier reports (Yonish-Rouach et al. 1994; Haupt et al. 1995), the majority of cells overexpressing wild-type p53 (Fig. 4A) also exhibited apoptotic features by DAPI staining (Fig. 4B). Several of the p53positive cells displayed highly condensed, often fragmented nuclear chromatin (thin arrow). Other cells, though positive for p53 overexpression, hardly displayed any DNA staining at all. Such "ghosts" (thick arrow) probably reflect the extensive loss of DNA from cells at advanced stages of apoptosis, owing to massive cleavage by intracellular nucleases (see also Gottlieb et al. 1994). To further substantiate the conclusion that the transfected cells were dying through apoptosis, cells were subjected to TUNEL analysis (Gavrieli et al. 1992). This assay detects cells containing double-stranded DNA breaks and has been used extensively as a marker for
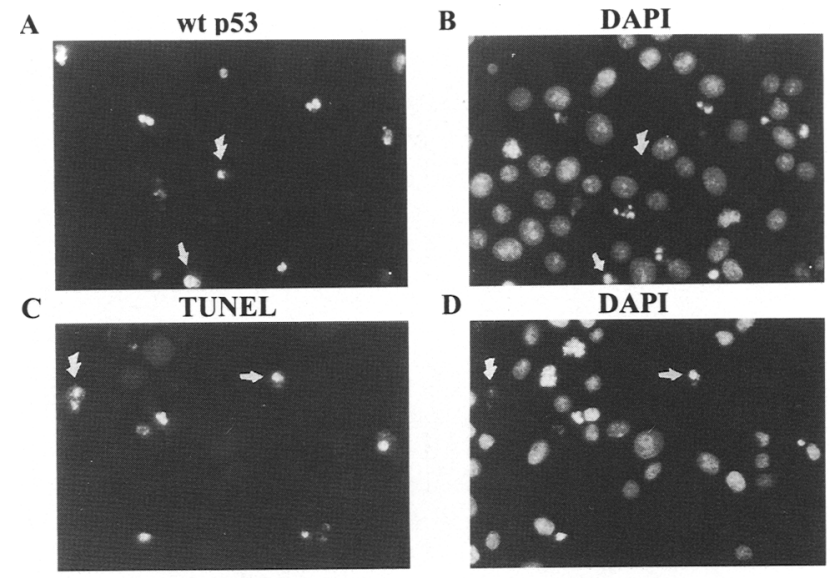

E $\mathrm{dl} 214$

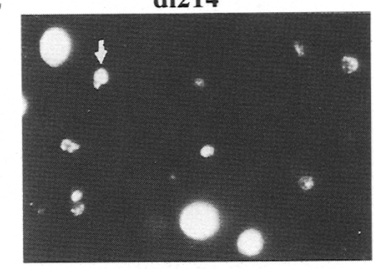

D DAPI

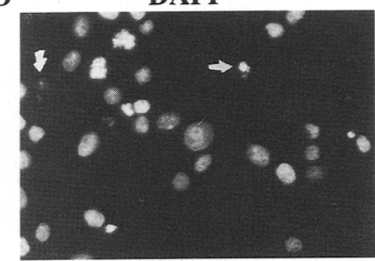

F

DAPI

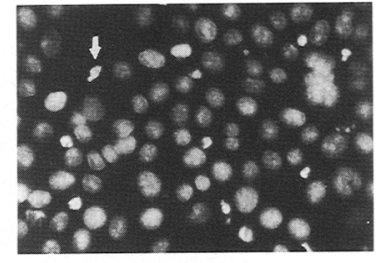

G

TUNEL

$\mathbf{H}$

DAPI
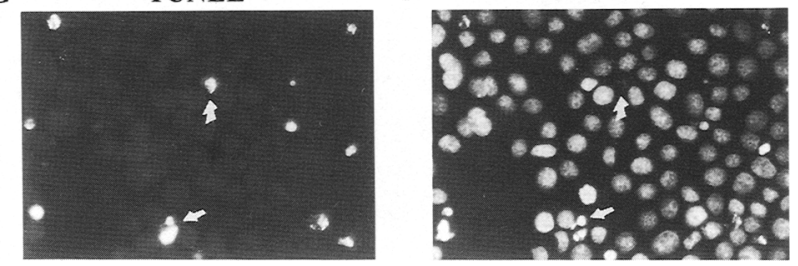

Figure 4. Immunofluorescent analysis of HeLa cells transfected with wild-type p53 or p53dl214. HeLa cells were transfected with pCMVp53wt $(A-D)$ or with pCMVp53d1214 $(E-H)$, as described in Fig. 3. Forty-eight hr later, one portion of the cells was fixed in methanol and stained with PAb248 $(A, E)$ or with DAPI $(B, F)$. Another portion of each transfected population was fixed in paraformaldehyde and stained by TUNEL $(C, G)$ or with DAPI $(D, H)$. Each pair of adjacent panels depicts the same field, viewed under two different wavelengths (see Materials and methods). Thin arrows indicate representative p53-positive cells with characteristic apoptotic nuclei; thick arrows indicate representative p53-positive ghosts.

apoptotic death (e.g., Gottlieb et al. 1994; Howes et al. 1994; Morgenbesser et al. 1994; Qin et al. 1994; Haupt et al. 1995). For TUNEL analysis, half the sample of transfected HeLa cells (from the same transfection dish as shown in Fig. 4, A and B) was fixed with paraformaldehyde rather than with methanol. Fixation with paraformaldehyde minimizes the loss of small chromatin fragments during subsequent manipulation /Gorczyca et al. 1993), even though cells that have lost much of their DNA before fixation will still appear as ghosts. Consequently, such fixation will result in fewer sub- $\mathrm{G}_{1}$ cells but will allow a more intense TUNEL staining. Fixed cells, containing double-stranded DNA breaks, were labeled with biotinylated dUTP in the presence of terminal deoxynucleotidyl transferase (Tdt), followed by rhodamine (TRITC)-conjugated streptavidin. During the 
second step, the cells were also stained with DAPI. The results for wild-type p53 (Fig. 4C,D) reveal a high correlation between TUNEL positivity and DAPI features typical of apoptosis, further establishing the validity of DAPI staining as a marker of apoptosis in this experimental system. Importantly, cells overexpressing p53d1214 also exhibited pronounced apoptotic characteristics, as visualized both by DAPI staining and by TUNEL (Fig. 4E-H). Relative to wild-type p53 transfectants, the p53dl214-positive cells contained a higher proportion of cells with visible condensed chromatin and a lower proportion of ghosts (Fig. 4, cf. A and B with E and F). In conclusion, like full-length wild-type p53, overexpressed p53d1214 induces a typical apoptotic response in transfected HeLa cells.

\section{A human p53 protein mutated in its trans-activation domain induces apoptosis in HeLa cells}

The results obtained with p53dl214 argued that, at least in HeLa cells, p53-mediated apoptosis can occur in the absence of SST. To further explore this possibility, a similar set of experiments was performed with plasmid pCMVp53Gln22,Ser23. This plasmid encodes full-length human $\mathrm{p} 53$, carrying two tandem point mutations at residues 22 and 23 (Lin et al. 1994). This mutant protein is markedly trans-activation deficient (Lin et al. 1994), probably because of its failure to interact with TFIID subunits, $\mathrm{TAF}_{\mathrm{II}} 40$ and $\mathrm{TAF}_{\mathrm{II}} 60$ (Thut et al. 1995).

First, the ability of p53Gln22,Ser23 to activate various p53-dependent promoters was tested in HeLa cells, under conditions essentially identical to those employed for apoptosis assays. As seen in Figure 5A, overexpression of p53Gln22,Ser23 did induce partial activation of a reporter plasmid driven by 17 tandem repeats of a RGC p53-binding site. On the other hand, no activation was seen at all when the effect of p53Gln22,Ser23 was determined on the cyclin G promoter (Fig. 5B), and only a very minimal effect was exerted on the p53-dependent, intronic $\mathrm{Mdm}-2$ promoter (Fig. $5 \mathrm{C}$ ). Unlike the synthetic RGC-based promoter, the latter two represent authentic p53-responsive promoters, derived from natural p53 target genes (Juven et al. 1993; Wu et al. 1993; Barak et al. 1994; Okamoto and Beach 1994; Zauberman et al. 1995). Hence, when assayed on relevant p53 targets, p53Gln $22, \operatorname{Ser} 23$ is a very inefficient trans-activator in HeLa cells.

Next, the ability of p53Gln 22 , Ser23 to induce apoptosis in transiently transfected HeLa cells was tested. As shown in Figure 6, p53Gln22, Ser23 was found to be a potent inducer of apoptosis in HeLa cells. Forty-eight hours post-transfection, the fraction of cells with sub-G $\mathrm{G}_{1}$ DNA content was $40 \%$ for p53Gln22,Ser23 (Fig. 6B), as compared to $49 \%$ for wild-type p53 (Fig. 6A). On the other hand, no apoptosis was triggered by the cancerderived mutant p53Gln179 (Fig. 6C). The cells in Figure $6, \mathrm{~A}$ and $\mathrm{B}$, are from the same experiment as the ones in Figure 5B and were transfected in parallel, under identical conditions, with aliquots of the same transfection mixture. Hence, a mutant, full-length human p53 pro-

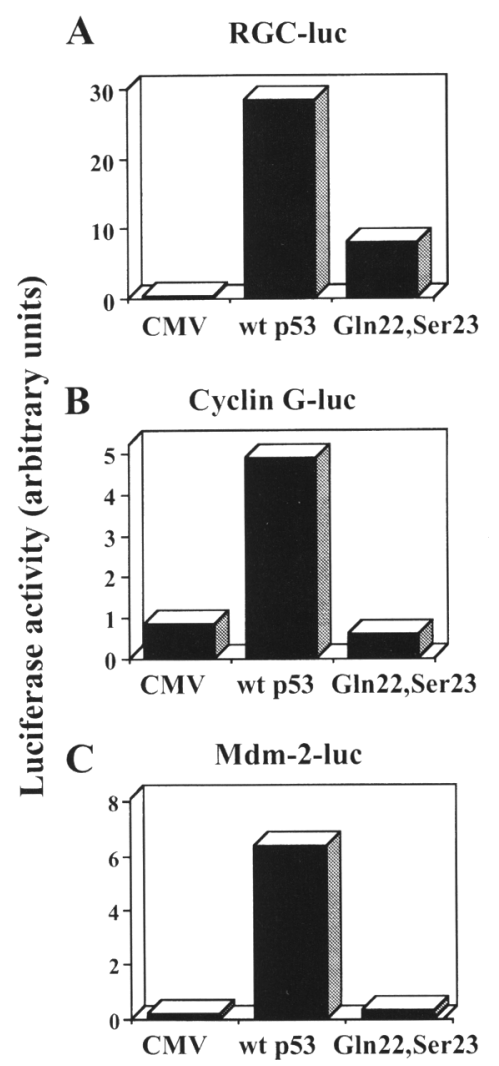

Figure 5. Transcriptional activity of wild-type p53 and p53Gln22,Ser23 in HeLa cells. Transfections were done essentially as in Fig. 2. HeLa cells $\left(6 \times 10^{5}\right.$ cells per $6-\mathrm{cm}$ dish) were transfected with $1 \mu \mathrm{g}$ of either RGC-luciferase $(A)$, cyclin G-luciferase $(B)$, or $\mathrm{Mdm}$-2-luciferase $(C)$ together with $1 \mu \mathrm{g}$ of the indicated expression plasmid. Luciferase activity was assayed $20 \mathrm{hr}$ post-transfection.

tein can induce extensive apoptosis in HeLa cells under conditions in which it is a very ineffective trans-activator of authentic p53-responsive promoters.

\section{p53dl214-induced apoptosis is efficient but is slower than that induced by wild-type p53}

The finding that p53dl214 and p53Gln22,Ser23 induce apoptosis in HeLa cells provided evidence for the involvement of an apoptotic pathway that is independent of transcriptional activation. Yet it did not exclude the possibility that trans-activation may also contribute to p53-mediated apoptosis, presumably through a second pathway that is dependent on the activation of p53-responsive genes. In the latter case, one would still expect intact wild-type p53 to be a more effective inducer of apoptosis than p53d1214.

This possibility was addressed by comparing the rate of death between cells transfected with wild-type p53 or with p53dl214. HeLa cells were transfected with equal amounts of DNA of each expression vector and analyzed by flow cytometry at different time points. The results are shown in Figure 7; in addition to wild-type p53 and 
A

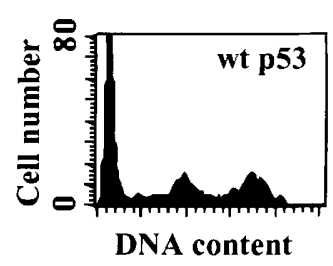

B

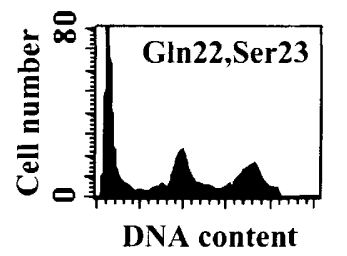

C

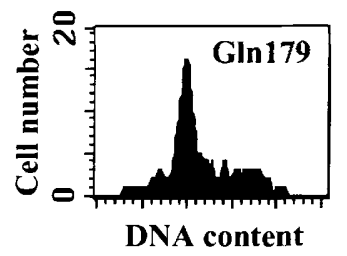

Figure 6. Induction of HeLa cell death by transfection with human 553 variants. Each 10 $\mathrm{cm}$ dish $\left(1.2 \times 10^{6}\right.$ cells $)$ was transfected with a combination of the indicated p53 expression plasmid $(2 \mu \mathrm{g} /$ dish) plus $2 \mu \mathrm{g}$ of cyclin G-luciferase DNA. The data are taken from the same experiment shown in Fig. 5B, employing the same transfection mixtures. Analysis was essentially as in Fig. 3, except that p53 staining was done with the human p53-specific monoclonal antibody DO-1. Only the subpopulations gated for high p53 expression are shown; the extent of spontaneous apoptosis in the untransfected population was negligible (data not shown). p53d1214, the experiment included the tumor-derived oncogenic mutant p53Phe132 (Halevy et al. 1990). A limited extent of apoptosis is seen in cells transfected by wild-type p53 as early as $24 \mathrm{hr}$ post-transfection. At 36 hr, a major fraction of the p53-positive cells already exhibited a sub-G $\mathrm{G}_{1}$ DNA content. In comparison, there were hardly any sub- $G_{1}$ cells $24 \mathrm{hr}$ after transfection with p53dl214, and at $36 \mathrm{hr}$ such cells were still a minority. A pattern comparable to that exhibited by the wild-type p53 transfectants at $36 \mathrm{hr}$, was seen in the p53d1214 transfectants after only $48 \mathrm{hr}$. Nevertheless, by $56 \mathrm{hr}$ the extent of apoptosis among cells overexpressing p53 d 214 became very prominent. Thus, although induction of apoptosis by p53 $\mathrm{d} 1214$ is very efficient, it occurs more slowly than when the process is triggered by wildtype p53.

At all time points, the sub- $\mathrm{G}_{1}$ fraction among cells transfected with the oncogenic p53Phe132 did not exceed the spontaneous background of $2 \%-10 \%$; the slight increase observed at late times was also seen in the total, largely nontransfected population and is probably attributable to the aging of the culture.

A quantitative analysis of these data is presented in Figure 8 , which also incorporates information from an additional experiment of the same type. It is evident again that whereas both wild-type p53 and p53d1214 can induce extensive HeLa cell death, wild-type p53 does it faster.

Trans-activation-deficient p53 can suppress oncogene-mediated transformation

The anti-proliferative activity of wild-type p53 is commonly monitored in two types of tissue culture assays, which are superficially similar. In one type, tumor cells lacking wild-type p53 (typically of human origin) are assessed for the ability of wild-type p53 to prevent the appearance of growing, drug-resistant colonies when its gene is transfected stably into the cells in conjunction with a selectable drug resistance marker (Baker et al. 1990/. In the other type of assay, one scores the ability of p53 to repress the development of transformed foci in rat embryo fibroblasts (REFs) stably transfected with various oncogene combinations (Crook et al. 1989; Eliyahu et al. 1989; Finlay et al. 1989). It is well accepted that the effect of p53 in the first type of system (drug-resistant colonies in the absence of any transfected oncogene) is strongly dependent on transcriptional activation /Crook

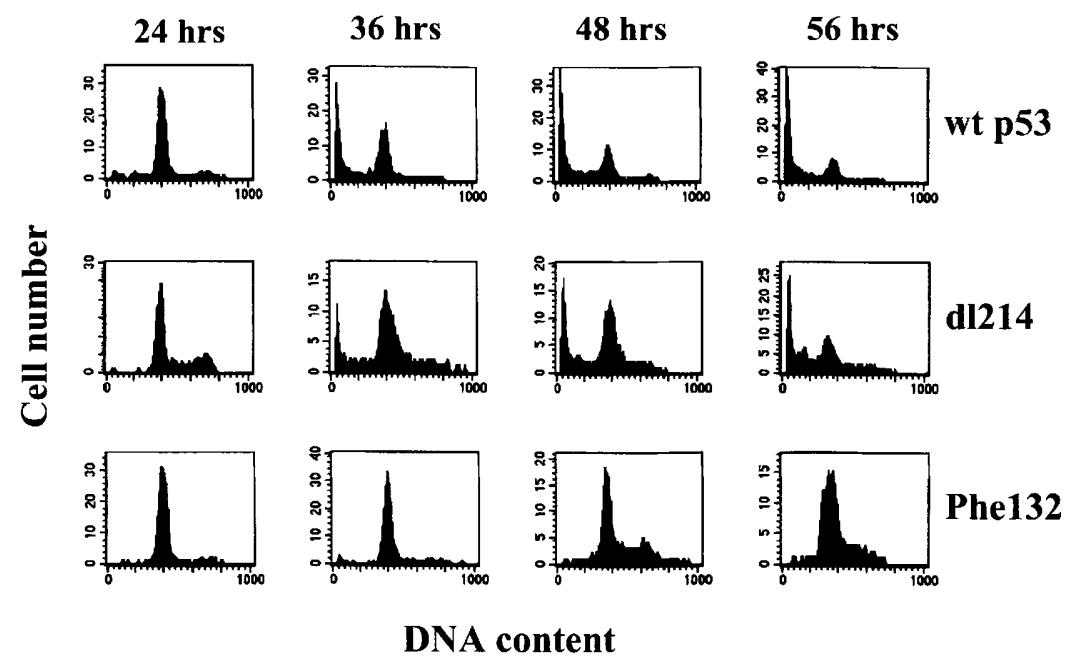

Figure 7. Kinetic analysis of apoptosis in HeLa cells transfected with various p53 expression plasmids. HeLa cells were transfected with $5 \mu \mathrm{g}$ of the indicated plasmid and collected at the indicated time points. All transfections and analyses were performed in parallel for each of the three plasmids. Cells were fixed with methanol, stained, and gated for $\mathrm{p} 53$ expression as described in Fig. 3. Individual panels depict the DNA content distribution of the corresponding p53-overexpressing subpopulation (as in Fig. 3D). In each case, the pattern exhibited by the total population remained normal (data not shown; see Fig. 3C). 
Figure 8. Time course of apoptosis mediated by wild-type p53, p53d1214, and p53Phe132. Percentages of sub- $G_{1}$ cells were calculated from analyses of the type described in Fig. 7. Each value represents an average of at least two independent experiments.

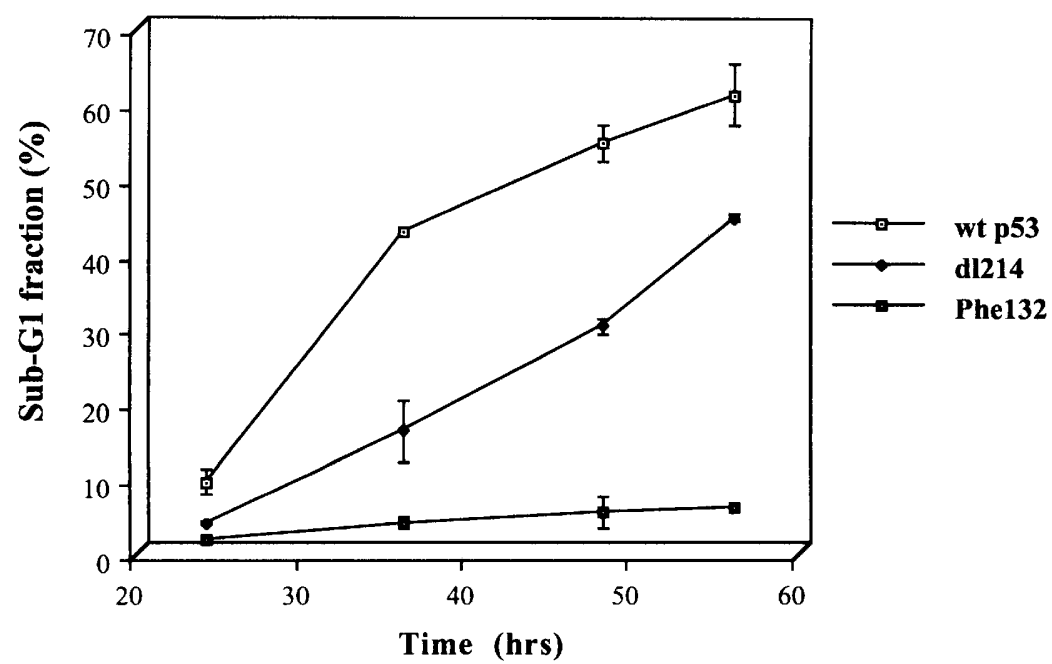

et al. 1994; Ory et al. 1994; Pietenpol et al. 1994). It is thus reasonable to assume that the REF assay will be affected similarly. However, recent data suggest that the two types of systems are not interchangeable; in particular, certain mutants that are present in human tumors, but nevertheless retain substantial trans-activation capacity, suppress effectively in the human cell-line assay but not in the REF assay (Crook et al. 1994). This raises the possibility that activities of p53 other than SST may dictate the effect of this protein on oncogene-mediated transformation of REF.

It was therefore of interest to determine whether p53dl214 had any effect on oncogene-mediated focus formation in REFs. REFs were transfected with a number of different oncogene combinations, together with expression plasmids for different forms of $\mathrm{p} 53$. Transformed foci were scored at appropriate times, and the results are shown in Figure 9.

Three oncogene combinations were tested: myc plus ras (Fig. 9A), adenovirus ElA plus ras (Fig. 9B), and human papillomavirus type 16 (HPV-16) E7 plus ras (Fig. 9C). The data in Figure 9C were obtained from experiments in which a selectable marker (neo) was also included, and transformed colonies were scored following G418 selection. However, similar results were obtained in an experiment that did not involve drug selection (data not shown). As expected, wild-type p53 exerted a strong inhibitory effect on focus formation by all three oncogene combinations tested. On the other hand, tumor-derived mutant mouse p53 actually elevated the number of transformed foci (Fig. 9A,B). This is consistent with earlier observations (Halevy et al. 1990; Hinds et al. 1990; Michalovitz et al. 1990; Shaulian et al. 1992) and probably reflects a dominant negative effect of the mutant protein on endogenous REF wild-type p53. In contrast, p53dl214 was quite a remarkable inhibitor of oncogene-mediated transformation. Under the experimental conditions employed for this study, p53dl214 exerted a substantial inhibitory effect on transformation of REFs by either myc plus ras (Fig. 9A) or E7 plus ras (Fig. 9C).
The effect was not as complete as that of wild-type p53, but was nevertheless very significant.

A less dramatic effect was seen when transformation was driven by E1A plus ras (Fig. 9B), suggesting that the transformation process triggered by this pair of oncogenes can tolerate at least some expression of $\mathrm{p} 53 \mathrm{dl} 214$. As predicted from the rather mild reduction in focus number caused by p53d 214 in the presence of E1A plus ras, many of the cell clones established from such foci synthesized the expected truncated p53dl214 polypeptide when analyzed at early passage (data not shown). However, the amount of $\mathrm{p} 53 \mathrm{dl} 214$ in these clones was very low, despite the fact that abundant expression of this polypeptide was induced by the same plasmid in transiently transfected REF (data not shown). Moreover, p53dl214 expression tended to become undetectable upon several consecutive cell passages in culture. It is conceivable that a similar process, already occurring during the growth of the primary foci in the transfected dish, is also responsible for the reduced level of p53d1214 expression in early-passage focus-derived clones. Hence, whereas REF transfected with E1A plus ras can tolerate a certain extent of $\mathrm{p} 53 \mathrm{dl} 214$ overexpression, there is a strong selection against stable overexpression of this truncated $\mathrm{p} 53$ derivative.

Overall, the data presented above argue that, when expressed at sufficiently high levels, trans-activation-deficient p53 can induce apoptosis in transiently transfected HeLa cells as well as inhibit focus formation in stably transfected REF. One should therefore invoke alternative pathways for at least some of the putative tumor suppressor activities of $\mathrm{p} 53$, which will not depend solely on the ability of p53 to function as a sequence-specific trans-activator.

\section{Discussion}

The data reported in this study demonstrate that the apoptotic death of HeLa cells can be triggered quite efficiently by a deleted form of p53, which does not exhibit 


\section{C ras+E7}

A

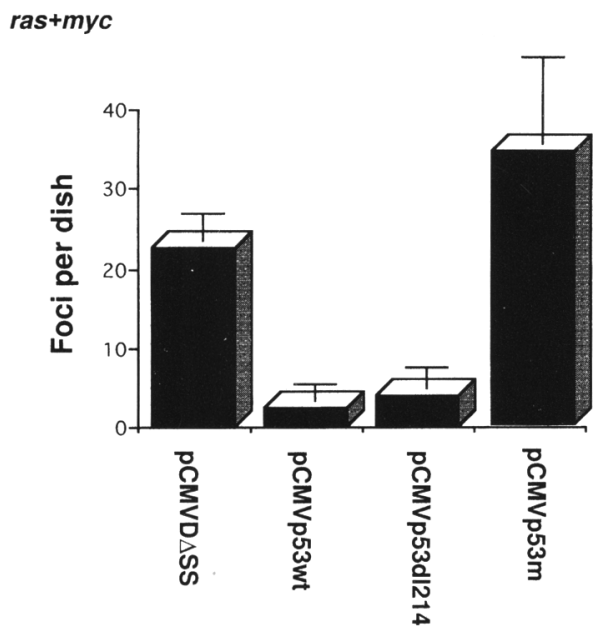

Cotransfected plasmid

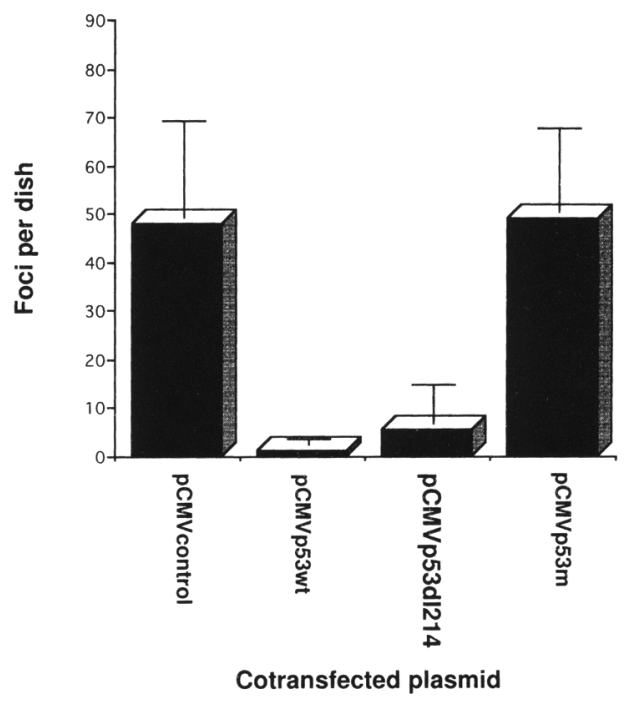

Figure 9. Suppression of oncogene-mediated transformation by wild-type $\mathrm{p} 53$ and by p53dl214. (A) REF were plated in 6-cm dishes $\left(4 \times 10^{5}\right.$ cells per dish) and transfected with a combination of pEJ6.6 (activated Ha-ras, $0.75 \mu \mathrm{g}$ ), pLTRmyc $(0.75 \mu \mathrm{g})$, and $2.5 \mu \mathrm{g}$ of the indicated $\mathrm{p} 53$ expression plasmid. Transformed foci were scored 10 days after transfection. Focus numbers were compiled from three independent experiments and are shown with standard deviation. (p53m) The p53Glu168,Ile234 double mutant (Eliyahu et al. 1988). pCMVD $\Delta S S$ encodes an oligomerization-deficient carboxy-terminal fragment of p53, which lacks demonstrable biological activity (Shaulian et al. 1992; Shaulian et al. 1995). (B) Experimental details identical to $A$, except that $0.75 \mu \mathrm{g}$ of plasmid pAd5Pst, encoding adenovirus type 5 E1A proteins, was used instead of pLTRmyc. (C) REF ( $3 \times 10^{5}$ cells per 9-cm dish) were cotransfected with a combination of $5 \mu \mathrm{g}$ of pEJ6.6, $2 \mu \mathrm{g}$ of pJ416E7, $1.5 \mu \mathrm{g}$ of pSV2neo, and $10 \mu \mathrm{g}$ of the indicated p53 expression plasmid. Transfected cells were selected with 250 $\mu \mathrm{g} / \mathrm{ml}$ of $\mathrm{G} 418$, and transformed colonies were scored 14 days after transfection. $(\mathrm{p} 53 \mathrm{~m}) \mathrm{p} 53 \mathrm{Phe} 132$. Values are compiled from three independent experiments. (pCMV control) Either pCMVD $\triangle S S$ or a control pCMV vector, used in different experiments; no significant differences were observed between transformation efficiencies in the presence of either of these two plasmids (data not shown). any measurable SST. Similarly, a p53 point mutant with an impaired trans-activation domain, which is markedly compromised in its ability to activate relevant target promoters in HeLa cells, still retains the ability to function as a potent inducer of apoptosis in the same cells. These observations argue strongly for the existence of an alternative p53-dependent pathway, which leads to apoptosis without requiring the activation of specific target genes. This model is consistent with reports by Caelles et al. (1994) and Wagner et al. (1994), who demonstrated that p53-mediated apoptosis can occur in the presence of RNA and protein synthesis inhibitors, suggesting that SST is dispensable for this process. A similar idea was proposed recently by Ishioka et al. (1995). Moreover, as p53d1214 lacks several of the most critical residues of p53's sequence-specific DNA-binding domain (Pavletich et al. 1993; Prives 1994), that alternative apoptotic pathway is likely to operate in a manner that does not require the binding of p53 to its consensus DNA sites. A model addressing these alternative apoptotic pathways, as well as the proposed role of the RB family proteins and the inverse relationship between $\mathrm{p} 53$-mediated $\mathrm{G}_{1}$ arrest and apoptosis, is presented in Figure 10.

One should exercise extreme caution in interpreting the data and particularly in concluding that transcriptional activation is not a key player in the apoptotic effects of p53. First, the transfected cells in our experimental system usually express very high levels of p53. As with other studies of this type, one needs to take into account phenomena that result from this vast overexpression. For instance, the amino terminus of p53 constitutes a potent trans-activation domain, which is fully contained within p53d1214. The concern arises, therefore, that overexpression of any trans-activation domain will induce apoptosis in HeLa cells, irrespective of the protein from which this domain is derived. Experiments with fusion proteins suggest that this is probably not the case. A protein fusing the GAL4 DNA-binding domain to 


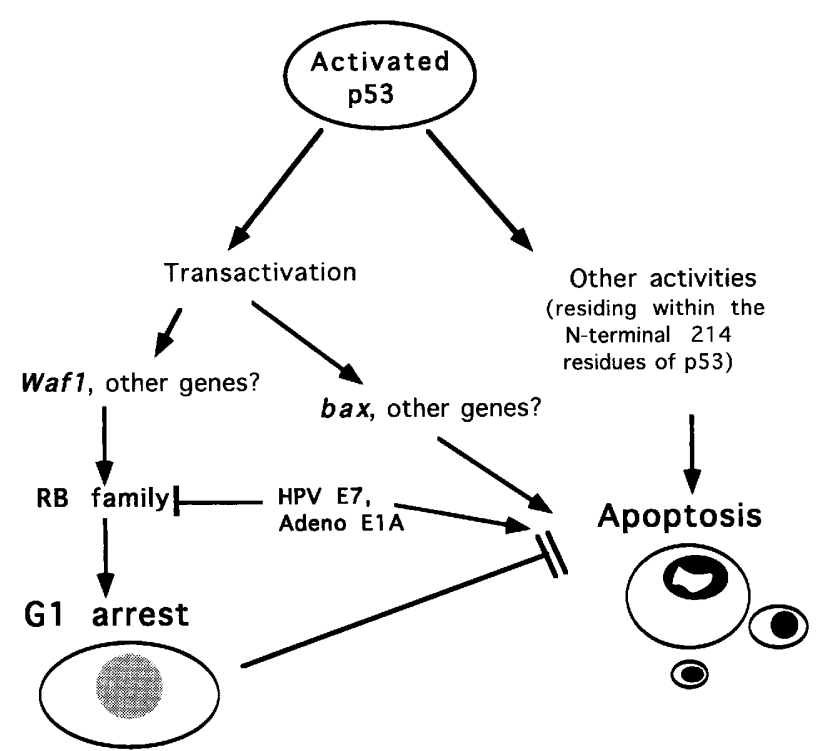

Figure 10. Dual signal model for p53-mediated apoptosis and $\mathrm{G}_{1}$ arrest. The model proposes that $\mathrm{G} 1$ arrest is induced exclusively through the trans-activation of target genes by p53, with a key role assigned to the induction of the Waf1 gene and the consequent activation of RB family proteins. In contrast, it is proposed that $\mathrm{p} 53$-mediated apoptosis is driven by two types of signals. On the one hand, p53 may contribute to the process by turning on specific target genes. These may include some that are also involved in the $\mathrm{G}_{1}$ arrest, as well as others that act only in the context of apoptosis (e.g., bax). On the other hand, p53 is proposed to mediate apoptosis through one or more activities that are distinct from and independent of its trans-activation capacity. It is proposed further that, at least under some circumstances, a proper $G_{1}$ arrest can inhibit apoptosis, whereas a failure to arrest in $G_{1}$ will trigger p53-mediated apoptosis. Inactivation of RB family proteins, either through mutations or epigenetically (e.g., by viral oncoproteins), will promote the latter option. For further discussion of the relationship between RB and p53-mediated apoptosis, see Haupt et al. (1995) and references therein.

the first 214 residues of mouse p53 induces apoptosis in transfected HeLa cells, albeit to a lesser extent than p53d1214 (data not shown). On the other hand, no significant apoptotic activity is exhibited by a fusion between the GAL4 DNA-binding domain and the VP16 trans-activation domain, even though the latter fusion protein is a potent trans-activator in HeLa cells (data not shown). One may assume then that the apoptotic response elicited by p53dl214 entails a distinct biochemical activity, or a particular molecular interaction, residing within the first 214 residues of p53. Yet it remains unknown whether the amounts of p53 present naturally in any cell could provide enough of this putative activity to trigger apoptosis.

Moreover, the fact that wild-type p53-mediated apoptosis occurs at a faster rate than that induced by p53d1214 raises the possibility that two p53-regulated apoptotic pathways exist, one that may depend on transcriptional activation. The effects of the two potential pathways, both of which are presumably triggered simul- taneously by activated wild-type p53, may be additive or even synergistic. Hence, cell death triggered by wild-type p53 will occur faster than when induced through a single pathway, as in the case of p53dl214. Consistent with these results is the observation that full-length wild-type p53 can induce apoptosis in HeLa cells at lower concentrations of transfected DNA $(<1 \mu \mathrm{g})$, whereas p53dl214 is an effective inducer of apoptosis at DNA concentrations only several fold higher (data not shown). Further support for a potential role of transcriptional activation in p53-mediated apoptosis derives from the identification of bax as a target gene for induction by p53 (Miyashita et al 1994; Miyashita and Reed 1995). Activation of Wafl by p53 can potentially account for the establishment of $a G_{1}$ arrest (El-Deiry et al 1993; Harper et al. 1993; Dulic et al. 1994) and the cessation of replicative DNA synthesis (Waga et al. 1994). Similarly, activation of Gadd45 (Kastan et al. 1992) can explain the block in replicative DNA synthesis, as well as promotion of DNA repair (Smith et al. 1994). On the other hand, overexpression of bax by $\mathrm{p} 53$ has so far been implicated only in the control of apoptosis (Selvakumaran et al. 1994; Zhan et al. 1994). Hence, elevation of bax levels by p53 may well be conceived as a direct contributor to apoptosis, at least within certain cellular contexts. In this regard, one might also mention another recently described p53 target-the cyclin $G$ gene-which is very strongly induced by excess wild-type p53 in a variety of cell types (Okamoto and Beach 1994; Zauberman et al. 1995). The consequences of cyclin $G$ induction are as yet unknown, but a role in p53-mediated apoptosis can not be excluded at present.

We also can not formally dismiss the possibility that p53d1214, despite lacking critical residues of p53's sequence-specific DNA-binding domain (Pavletich et al. 1993; Prives 1994) and failing to trans-activate typical p53 targets, can nevertheless induce the specific expression of genes as yet unknown. Such activation may be indirect and rely on protein-protein interaction between p53 and different sequence-specific DNA-binding proteins. As p53d1214 retains the entire trans-activation domain (Unger et al. 1992), such putative interaction could result in the activation of a unique set of genes, which do not carry a recognizable p53-responsive element. A similar argument could be made for p53Gln22, Ser23; although failing to activate significantly two authentic p53 target promoters in HeLa cells, this mutant does activate partially an artificial promoter bearing multiple p53-binding sites. One cannot rule out the possibility that some authentic p53 target genes exist that are responsive to p53Gln22,Ser23. Such responsiveness could account, at least in part, for the effective induction of apoptosis by this mutant.

An additional caution involves the fact that HeLa cells express endogenous wild-type p53. Although the amount of this protein is extremely low, the possibility that it does contribute to some extent to the observed apoptosis cannot be ruled out. In particular, this could apply to the human $\mathrm{p} 53 \mathrm{G} \ln 22, \mathrm{Ser} 23$. This protein is expected to interact efficiently with the HPV E6 protein in HeLa cells. 
Competition for E6 is likely to increase, to some extent, the levels of endogenous HeLa p53, and thereby facilitate apoptosis. Nevertheless, the data in Figure 5 argue that such an increase in endogenous p53, if present, is not sufficient to activate significantly reporter constructs driven by typical wild-type authentic p53-responsive promoters. Furthermore, accumulation of endogenous p53 through competition for E6 is less likely to be engendered by the murine, carboxy-terminally truncated p53dl214. In line with this contention, p53dl214 does not activate at all even the artificial, RGC-based reporter (Fig. 2), which does display partial activation in HeLa cells transfected with p53Gln22,Ser23 (Fig. 5). It is also of note that a p53 molecule lacking the bulk of the transactivation domain (p53dl13-52, Fig. 3I) completely fails to induce apoptosis. This result identifies the deleted residues as essential for the apoptotic effects of p53 and suggests that at least some of the activity contributed by p53 dl214 may reside within this domain. At the same time, the failure of p53dl13-52 to trigger apoptosis would also argue that the endogenous HeLa p53, on its own, is totally incapable of activating the apoptotic pathway under the conditions of our assay. Thus, a distinct additional activity, retained in p53 $\mathrm{dl} 214$, is indispensable. Even so, it is still conceivable that the endogenous wild-type p53 contributes to the observed cell death, perhaps through a mechanism undetectable by standard SST assays. Our data thus remain compatible with the possibility that HeLa apoptosis is brought about by the combined effect of an SST-independent activity of p53 and a minimal amount of a distinct, perhaps SST-related activity contributed by the intact wild-type protein.

Despite all of the above reservations, the most likely interpretation of our data remains that a trans-activation-independent pathway for p53-mediated apoptosis exists. Which other activities of p53 might then account for this alternative apoptotic pathway? One possibility that comes to mind is the capacity of wild-type p53 to repress transcription from a wide array of promoters (Ginsberg et al. 1991; Santhanam et al. 1991; Subler et al. 1992; Mack et al. 1993). Potential support for the contention that transcriptional repression by p 53 may be important for apoptosis is offered by observations related to $\mathrm{Bcl}-2$ and to the adenovirus E1B $19-\mathrm{kD}$ protein. Bcl-2 is an efficient blocker of p53-mediated apoptosis (Wang et al. 1993; Chiou et al. 1994). Interestingly, it also appears to relieve p53-mediated transcriptional repression without compromising the potential of $\mathrm{p} 53$ for sequencespecific trans-activation (Shen and Shenk 1994). Essentially similar findings were described for the adenovirus E1B $19 \mathrm{kD}$ protein (Sabbatini et al. 1995), another potent inhibitor of p53-mediated apoptosis (Debbas and White 1993). It is of note that overexpression of wild-type p53 can also repress the expression of the $b c l-2$ gene (Haldar et al. 1994; Miyashita et al. 1994; Selvakumaran et al. 1994), thereby suggesting a positive feedback loop whereby the reduction of $b c l-2$ expression further potentiates the ability of wild-type p53 to repress a variety of target promoters. However, as yet there is no direct proof that transcriptional repression by p 53 can actually elicit apoptosis. Because the amino-terminal end of p53 may engage in a large variety of interactions and activities, unequivocal evidence for a cause-and-effect relationship between p53-mediated transcriptional repression and apoptosis may be very difficult to obtain.

In a broader context, it is conceivable that the apoptotic effect of p53dl214 may rely on its specific interaction with one or more critical proteins. Such proteins may, potentially serve as effectors of the apoptotic functions of p53. Therefore, it will be of great interest to identify protein-protein interactions whose disruption (e.g., by mutations) abolishes p53d1214-triggered apoptosis. In this regard, it is noteworthy that the amino-terminal portion of $\mathrm{p} 53$, retained within $\mathrm{p} 53 \mathrm{dl} 214$, also includes the region required for binding to the $\mathrm{Mdm}-2$ protein (Chen et al. 1993; Oliner et al. 1993; Haines et al. 1994). This protein-protein interaction, although occurring within the trans-activation domain of $\mathrm{p} 53$, appears to be unrelated to the trans-activation capacity of p53 (Lin et al. 1994; Marston et al. 1994). The question therefore arises as to whether $\mathrm{Mdm}-2$ binding may account for the alternative $\mathrm{p} 53$-mediated apoptotic activity. The latter is unlikely in the case of p53Gln22,Ser23, as this mutant fails to bind Mdm-2 (Lin et al. 1994). However, the contribution of such interactions to the effects of p53dl214 remains unknown.

The data reported in this study might explain the intriguing observation that SST can be linked tightly to the inhibitory effects of p53 in some experimental systems (e.g., drug-resistant colonies of transfected human tumor cell lines) but not others (e.g., oncogene-mediated REF transformation) (Crook et al. 1994; Zhang et al. 1994). As shown in Figure 9, the trans-activation-deficient p53dl214 can inhibit REF transformation by at least certain oncogene combinations. In view of the ability of p53dl214 to induce apoptosis in HeLa cells, it is conceivable that p53-mediated suppression of REF transformation involves the induction of apoptosis. The ability of monomeric p53 proteins such as p53dl303 to inhibit effectively REF transformation, despite possessing a markedly reduced trans-activation potential (Shaulian et al. 1995), is probably another reflection of the same situation. The relative contribution of each p53-mediated pathway (growth arrest, trans-activation-dependent apoptosis, and trans-activation-independent apoptosis) may vary greatly as a function of the cell type and the overall balance of growth-inhibitory and growth-stimulatory signals to which the cell is exposed. In that respect, it is noteworthy that all three nuclear proteins used here in the REF assay-Myc, adenovirus E1A, and HPV E7-are known to promote p53-mediated apoptosis under a variety of conditions (Debbas and White 1993; Lowe and Ruley 1993; Demers et al. 1994; Hermeking and Eick 1994; Hickman et al. 1994; Howes et al. 1994; Pan and Griep 1994; Slebos et al. 1994; Wagner et al. 1994). It is probably not coincidental that p53dl214 exerts prominent apoptotic effects in HeLa cells, which constitutively express the HPV-18 E7 protein. It is tempting to speculate that the same holds true for primary human tumor cells. Thus, whereas in some tumors the main 
selective pressure may be directed against p53's ability to induce a $G_{1}$ arrest through SST, other tumor types will be selected primarily for loss of wild-type p53-mediated apoptosis. In some of the latter cases, trans-activation-independent activities of p53 may be preferentially targeted by genetic alterations found in the advanced tumor.

Finally, a recent study by Sabbatini et al. (1995) has addressed questions similar to those discussed here. Using stable transfection of baby rat kidney (BRK) cells with adenovirus ElA plus a temperature-sensitive version of the p53Gln22,Ser23, they found that the latter protein has lost its ability to trigger apoptosis at the permissive temperature of $32^{\circ} \mathrm{C}$. Nevertheless, this protein was still capable of forcing a pronounced growth arrest. Taken together, both studies suggest that p53 possesses a cell-inhibitory activity that appears to be independent of SST. Very much like cellular responses to excess intact wild-type p53 (Oren 1994; Wu and Levine 1994; Canman et al. 1995), the phenotypic consequences of this distinct activity will depend greatly on the cellular context. Thus, whereas this activity may culminate in apoptosis in HeLa cells, it may lead to a viable growth arrest in other cell types.

\section{Materials and methods}

\section{Cells and transfection}

HeLa cells were grown at $37.5^{\circ} \mathrm{C}$ in Dulbecco's modified Eagle medium (DMEM) supplemented with $10 \%$ fetal calf serum (FCS). Cells were plated out $24 \mathrm{hr}$ before transfection at $1 \times 10^{6}$ cells per $10-\mathrm{cm}$ dish (for flow cytometric analysis and immunostaining) or at $5 \times 10^{5}$ cells per $6-\mathrm{cm}$ dish (for luciferase assay). HeLa cells were transfected by the calcium phosphate method; the DNA precipitate was left on the cells overnight, and then cells were shocked with medium containing $10 \%$ glycerol for 1 min. Whenever required, pCMV-Neo-Bam was used to maintain a constant amount of DNA in each sample.

Hybridoma cells were grown at $37.5^{\circ} \mathrm{C}$ in RPMI supplemented with $10 \%$ FCS, glutamine, and $\beta$-mercaptoethanol $(50$ $\mu \mathrm{M})$. Cells were grown to high density $(<50 \%$ viability) before being harvested. Hybridoma supernatants were used either directly or after antibody purification (see below).

REFs were maintained at $37.5^{\circ} \mathrm{C}$ in DMEM supplemented with $10 \%$ FCS. Twenty hr before transfection, cells were plated at $4 \times 10^{5}$ cells per $6-\mathrm{cm}$ dish. REFs were transfected with the indicated amount of plasmid using the calcium phosphate method. For drug (neo) selection, cells were grown in $250 \mu \mathrm{g} / \mathrm{ml}$ of G418; the medium was changed every 4 days. Foci were scored 10 days after transfection.

Luciferase assays and Western blot analysis were carried out essentially as described previously (Haupt et al. 1995).

\section{Plasmids}

The following plasmids, encoding different forms of murine wild-type p53 under the CMV immediate early promoter/enhancer, were used: pCMVp53wt, encoding wild-type p53 (Eliyahu et al. 1989); pCMVd1330, pCMVdl303, and pCMVD $\Delta S$ (Shaulian et al. 1992; Shaulian et al. 1993); pCMVdl214 and pCMVd113-52 (this paper); pCMVPhe132 (Halevy et al. 1990) and pCMVp53Ile234,Glu168 (Eliyahu et al. 1988; Eliyahu et al. 1989). As a vector control, pCMV-Neo-Bam (Baker et al. 1990) was used.
pCMVd1214 was constructed by cleaving plasmid pCMVp53wt with KpnI, followed by re-ligation of the backbone plasmid. To construct pCMVdl13-52, an XhoI site was introduced by PCR at a position corresponding to residue 52 of mouse p53. The XhoI-KpnI fragment of the amplified product was then used to replace the XhoI-KpnI segment of pCMVp53wt.

The following plasmids were employed for transformation assays: pLTRmyc, pEJ6.6 (see Michalovitz, et al. 1990), pAd5Pst, driving the expression of adenovirus $512 \mathrm{~S}$ and $13 \mathrm{~S}$ E1A mRNA (Jochemsen et al. 1984), and pMoE7, encoding HPV16 E7 (Edmonds and Vousden 1989).

The reporter plasmid pRGCLuc contains 17 copies of the RGC p53-binding site (Kern et al. 1991) in front of a luciferase gene. Cyclin G-luc contains the promoter, exon I, and part of intron I of the rat cyclin $G$ gene, including two p53-binding sites (Zauberman et al. 1995) linked to luciferase (plasmid constructed by A. Zauberman). Mdm-2-luc contains the ApaI-NsiI fragment of the mouse $m d m-2$ gene, including the intronic p53dependent promoter (Juven et al. 1993), in front of luciferase.

Plasmid pCMVIL-2R encodes the extracellular and transmembrane domains (gp55 subunit) of the human IL-2R (LaFlamme et al. 1992).

\section{Indirect immunofluorescence}

HeLa cells were plated and transfected as described above. At the indicated time point, adherent cells were combined with cells that had detached and were floating in the medium. Cells were washed in cold PBS, fixed in cold methanol $\left(-20^{\circ} \mathrm{C}\right)$ for at least $20 \mathrm{~min}$, and rehydrated in cold PBS for at least $30 \mathrm{~min}$ at $4^{\circ} \mathrm{C}$. For microscopic analysis, cells were spun onto slides using a Cytospin (Shandon Elliott) at $700 \mathrm{rpm}$ for $5 \mathrm{~min}$. Cells were blocked with $1 \%$ BSA for $5 \mathrm{~min}$, rinsed with PBS, and incubated with a mouse-specific p53 monoclonal antibody, PAb248, for 30 min at $37^{\circ} \mathrm{C}$. To detect transfected IL-2R, similar staining was performed with the monoclonal antibody 7G7B6 (ATCC HB 8784). Slides were washed three times with PBS and incubated with TRITC-conjugated goat anti-mouse IgG + IgM (Jackson Immunoresearch Laboratories) for $30 \mathrm{~min}$ at $37^{\circ} \mathrm{C}$. The last incubation contained DAPI $(0.5 \mu \mathrm{g} / \mathrm{ml}$, Sigma $)$ for DNA staining. Slides were washed three times in PBS, covered with coverslips, and viewed under the fluorescence microscope (Zeiss Axioskop) for red fluorescence (rhodamine) at $570 \mathrm{~nm}$ and for DAPI at $420 \mathrm{~nm}$.

For TUNEL analysis, cells were harvested and washed as described above. Washed cells were fixed in $3 \%$ paraformaldehyde for $30 \mathrm{~min}$ at room temperature, washed in PBS, and spun onto slides as described above. Slides were rinsed and incubated in a $\mathrm{Co}^{2+}$ reaction buffer containing $40 \mu \mathrm{M}$ biotin-16-dUTP (Boehringer) and 10 units of $\mathrm{Ttd}$ (IBI chemicals) for $\mathrm{l} \mathrm{hr}$ at $37^{\circ} \mathrm{C}$. Nonspecific binding was blocked by incubation with $1 \%$ BSA for $5 \mathrm{~min}$. Slides were washed in $2 \times$ SSC for $15 \mathrm{~min}$, rinsed in PBS, and incubated with ExtraAvidin-TRITC at 1:50 dilution and DAPI at $0.5 \mu \mathrm{g} / \mathrm{ml}$ in PBS at $37^{\circ} \mathrm{C}$ for $30 \mathrm{~min}$. Slides were washed twice in PBS, covered with coverslips, and viewed under the fluorescence microscope.

\section{Flow cytometry}

At the indicated times post-transfection, adherent and floating cells were combined and washed in cold PBS. Cells were fixed in methanol for at least $20 \mathrm{~min}$ at $-20^{\circ} \mathrm{C}$, rehydrated in PBS for a minimum of $30 \mathrm{~min}$ at $4^{\circ} \mathrm{C}$, and reacted with the primary antibody (PAb248 for p53, or 7G7B6 for IL-2R) for $30 \mathrm{~min}$ at room temperature. PAb248 was used either as unconjugated antibody or as an FITC-conjugated antibody. Cells were washed twice in PBS and incubated, when appropriate, with a goat anti-mouse 
FITC-conjugated secondary antibody (Jackson) for $30 \mathrm{~min}$ at room temperature. Following incubation, cells were washed in PBS and treated with RNase A $(50 \mu \mathrm{g} / \mathrm{ml})$ for $20 \mathrm{~min}$. To stain DNA, PI $(25 \mu \mathrm{g} / \mathrm{ml}$, Sigma) was added to the cells. Samples were then analyzed in a cell sorter (FACSCAN or FACSORT, Becton Dickinson). Relative levels of p53 per cell were measured by FITC fluorescence intensity. A region defining high FITC fluorescence was determined, and cells falling into this region were collected separately. Equal numbers of events from the total population and from the gated subpopulation were recorded separately. The PI staining was recorded simultaneously in the red channel.

\section{Preparation of FITC-conjugated monoclonal antibody}

The PAb248 monoclonal antibody was purified from PAb248 hybridoma supernatant on a protein A-Sepharose column. Purified antibody $\left(2 \mathrm{mg} / \mathrm{ml}\right.$ in $0.1 \mathrm{M} \mathrm{NaHCO}_{3}$ at $\left.\mathrm{pH} 9.0\right)$ was conjugated to FITC $(1.5 \mathrm{mg} / \mathrm{ml}$ in DMSO, Molecular Probes) by incubating $0.15 \mathrm{mg}$ of FITC (diluted in DMSO) per $1 \mathrm{ml}$ of antibody for $2 \mathrm{hr}$ at room temperature. Unbound FITC was removed by gel filtration through a Sephadex G- 25 column. Before use for FACS analysis, the conjugated antibody was titrated for maximal specific activity.

\section{Acknowledgments}

We thank A. Kazaz for excellent technical assistance, Drs. J. Lin and A.J. Levine for the gifts of pCMVp53Gln22,Ser23, Dr. B. Geiger for the gifts of the IL-2R expression vector and the 7G7B6 monoclonal antibody, Dr. T. Unger for GAL4-human p53 fusions, A. Zauberman for cyclin G-luc, Dr. R. Haffner for the construction of pCMVPhe132, and Drs. A. Jochemsen and S. van den Heuvel for the gift of pAd5Pst. We thank Dr. E. YonishRouach for helpful discussions, and Dr. M. Kastan for advice on TUNEL staining. Y.H. is a recipient of a long-term European Molecular Biology Organization fellowship. This work was supported in part by U.S. Public Health Service grant RO1 CA 40099 from the National Cancer Institute, by grants from the Revson Science Foundation administered by the Israel Academy of Sciences and Humanities and the Israel-USA Binational Science Foundation, and by the Leo and Julia Forchheimer Center for Molecular Genetics.

The publication costs of this article were defrayed in part by payment of page charges. This article must therefore be hereby marked "advertisement" in accordance with 18 USC section 1734 solely to indicate this fact.

\section{References}

Baker, S.J., S. Markowitz, E.R. Fearson, J.K.V. Willson, and B. Vogelstein. 1990. Suppression of human colorectal carcinoma cell growth by wild-type p53. Science 249: 912-915.

Barak, Y., E. Gottlieb, T. Juven-Gershon, and M. Oren. 1994. Regulation of $\mathrm{mdm} 2$ expression by p53: Alternative promoters produce transcripts with nonidentical translation potential. Genes \& Dev. 8: 1739-1749.

Berns, A. 1994. Is p53 the only real tumor suppressor gene? Curr. Biol. 4: 137-139.

Caelles, C., A. Helmberg, and M. Karin. 1994. p53-dependent apoptosis in the absence of transcriptional activation of $\mathrm{p} 53$ target genes. Nature 370: 220-223.

Canman, C.E., T.M. Gilmer, S.B. Coutts, and M.B. Kastan. 1995. Growth factor modulation of p53-mediated growth arrest versus apoptosis. Genes \& Dev. 9: 600-611.

Chen, J.D., V. Marechal, and A.J. Levine. 1993. Mapping of the p53 and mdm-2 interaction domains. Mol. Cell Biol. 13:
$4107-4114$.

Chiou, S.-K., L. Rao, and E. White. 1994. Bcl-2 blocks p53-dependent apoptosis. Mol. Cell Biol. 14: 2556-2563.

Clarke, A.R., S. Gledhill, M.L. Hooper, C.C. Bird, and A.H. Wyllie. 1994. p53 dependence or early apoptotic and proliferative responses within the mouse intestinal epithelium following gamma-irradiation. Oncogene 9: 1767-1773.

Crook, T., J.P. Morgenstern, L. Crawford, and L. Banks. 1989. Continued expression of HPV-16 E7 protein is required for maintenance of the transformed phenotype of cells co-transfected by HPV-16 plus EJ-ras. EMBO J. 8: 513-519.

Crook, T., N.J. Marston, E.A. Sara, and K.H. Vousden. 1994. Transcriptional activation by p53 correlates with suppression of growth but not transformation. Cell 79: 817-827.

Darzynkiewicz, Z., S. Bruno, G. Delbino, W. Gorczyca, M.A. Hotz, P. Lassota, and F. Traganos. 1992. Features of apoptotic cells measured by flow cytometry. Cytometry 13: 795-808.

Debbas, M. and E. White. 1993. Wild-type p53 mediates apoptosis by E1A, which is inhibited by E1B. Genes \& Dev. 7: 546-554.

Demers, G.W., S.A. Foster, C.L. Halbert, and D.A. Galloway. 1994. Growth arrest by induction of p53 in DNA damaged keratinocytes is bypassed by human papillomavirus $16 \mathrm{E} 7$. Proc. Natl. Acad. Sci.. 91: 4382-4386.

Donehower, L.A. and A. Bradley. 1993. The tumor suppressor p53. Biochim. Biophys. Acta 1155: 181-205.

Dulic, V., W.K. Kaufmann, S.J. Wilson, T.D. Tlsty, E. Lees, J.W. Harper, S.J. Elledge, and S.I. Reed. 1994. p53-dependent inhibition of cyclin-dependent kinase activities in human fibroblasts during radiation-induced G1 arrest. Cell 76: 10131023.

Edmonds, C. and K.H. Vousden. 1989. A point mutational analysis of human papillomavirus type $16 \mathrm{E} 7$ protein. I. Virol. 63: 2650-2656.

El-Deiry, W.S., T. Tokino, V.E. Velculescu, D.B. Levy, R. Parsons, J.M. Trent, D. Lin, W.E. Mercer, K.W. Kinzler, and B. Vogelstein. 1993. WAF1, a potential mediator of p53 tumor suppression. Cell 75: 817-825.

El-Deiry, W.S., J.W. Harper, P.M. O'Connor, V.E. Verculescu, C.E. Canman, J. Jackson, J.A. Pietenopol, M. Burrell, D.E. Hill, Y. Wang, W.K. Wiman, W.E. Mercer, M.B. Kastan, K.W. Kohn, S.J. Elledge, K.W. Kinzler, and B. Vogelstein. 1994. WAF1/CIP1 is induced in p53-mediated G1 arrest and apoptosis. Cancer Res. 54: 1169-1174.

Eliyahu, D., N. Goldfinger, O. Pinhasi-Kimhi, G. Shaulsky, Y. Skurnik, N. Arai, V. Rotter, and M. Oren. 1988. Meth A fibrosarcoma cells express two transforming mutant p53 species. Oncogene 3: 313-321.

Eliyahu, D., D. Michalovitz, S. Eliyahu, O. Pinhasi-Kimhi, and M. Oren. 1989. Wild-type p53 can inhibit oncogene-mediated focus formation. Proc. Natl. Acad. Sci.. 86: 8763-8767.

Finlay, C.A., P.W. Hinds, and A.J. Levine. 1989. The p53 protooncogene can act as a suppressor of transformation. Cell 57: 1083-1093.

Friend, S. 1994. p53: A glimpse at the puppet behind the shadow play. Science. 334-335.

Gavrieli, Y., Y. Sherman, and S.A. Ben-Sasson. 1992. Identification of programmed cell death in situ via specific labeling of nuclear DNA fragmentation. J. Cell Biol. 119: 493-501.

Ginsberg, D., F. Mechta, M. Yaniv, and M. Oren. 1991. Wildtype p53 can down-modulate the activity of various promoters. Proc. Natl. Acad. Sci.. 88: 9979-9983.

Gorczyca, W., G. Jianping, and Z. Darzynkiewicz. 1993. Detection of DNA strand breaks in individual apoptotic cells by the in situ terminal deoxynucleotidyl transferase and nick translation assays. Cancer Res. 53: 1945-1951. 
Gottlieb, E., R. Haffner, T. von Ruden, E.F. Wagner, and M. Oren. 1994. Down-regulation of wild-type p53 activity interferes with apoptosis of IL-3-dependent hematopoietic cells following IL-3 withdrawal. EMBO J. 13: 1368-1374.

Haffner, R. and M. Oren. 1995. p53: Biochemical properties and biological effects. Curr. Opin. Genet. Dev. 5: 84-90.

Haines, D.S., J.E. Landers, L.J. Engle, and D.L. George. 1994. Physical and functional interaction between wild-type p53 and $\mathrm{mdm} 2$ proteins. Mol. Cell Biol. 14: 1171-1178.

Haldar, S., M. Negrini, M. Monne, S. Sabbioni, and C.M. Croce. 1994. Down-regulation of bcl-2 by p53 in breast cancer cells. Cancer Res. 54: 2095-2097.

Halevy, O., D. Michalovitz, and M. Oren. 1990. Different tumor derived p53 mutants exhibit distinct biological activities. Science 250: 113-116.

Harper, J.W., G.R. Adami, N. Wei, K. Keyomarsi, and S.J. Elledge. 1993. The p21 CDK-Interacting protein cipl is a potent inhibitor of G1 cyclin-dependent kinases. Cell 75: 805-816.

Harris, C.C. and M. Hollstein. 1993. Clinical implications of the p53 tumor-suppressor gene. N. Engl. J. Med. 329: 1318-1327.

Haupt, Y., S. Rowan, and M. Oren. 1995. p53-mediated apoptosis in HeLa cells can be overcome by excess pRB. Oncogene 10: $1563-1571$.

Hermeking, H. and D. Eick. 1994. Mediation of c-myc-induced apoptosis by p53. Science 265: 2091-2093.

Hickman, E.S., S.M. Picksley, and K.H. Vousden. 1994. Cells expressing HPV16 E7 continue cell cycle progression following DNA damage induced p53 activation. Oncogene 9: 2177-2181.

Hinds, P.W., C.A. Finlay, S.J. Quartin, E.R. Baker, B. Fearon, B. Vogelstein, and A.J. Levine. 1990. Mutant p53 DNA clones from human colon carcinomas cooperate with ras in transforming primary rat cells - a comparison of the hot spot mutant phenotype. Cell Growth Differ. 1: 571-580.

Hoppe-Seyler, F. and K. Butz. 1993. Repression of endogenous p53 transactivation function in HeLa cervical carcinoma cells by human papillomavirus Type-16 E6, human MDM-2, and mutant p53. I. Virol. 67: 3111-3117.

Howes, K.A., N. Ransom, D.S. Papermaster, J.G.H. Lasudry, D.M. Albert, and J.J. Windle. 1994. Apoptosis or retinoblastoma: Alternative fates of photoreceptors expressing the HPV-16 E7 gene in the presence or absence of p53. Oncogene 8: $1300-1310$.

Ishioka, C., C. Englert, P. Winge, Y.-X. Yan, M. Engelstein, and S.H. Friend. 1995. Mutational analysis of the carboxy-terminal portion of p53 using both yeast and mammalian cell assays in vivo. Oncogene 10: 1485-1492.

Jochemsen, A.G., J.L. Bos, and A.J. van der Eb. 1984. The first exon of region ElA genes of adenovirus 5 and 12 encodes a separate functional protein domain. EMBO J. 3: 2293-2297.

Johnson, P., S. Chung, and S. Benchimol. 1993. Growth suppression of Friend virus-transformed erythroleukemia cells by p53 protein is accompanied by hemoglobin production and is sensitive to erythropoietin. Mol. Cell Biol. 13: 1456-1463.

Juven, T., Y. Barak. A. Zauberman, D.L. George, and M. Oren. 1993. Wild type p53 can mediate sequence-specific transactivation of an internal promoter within the mdm2 gene. Oncogene 8: 3411-3416.

Kastan, B.M., Q. Zhan, W.S. El-Deiry, F. Carrier, T. Jacks, W.V. Walsh, B.S. Plunkett, B. Vogelstein, and A.J. Fornace. 1992. A mammalian cell cycle checkpoint pathway utilizing p53 and GADD45 is defective in ataxia-telangiectasia. Cell 71: 587597.

Kern, S.E., K.W. Kinzler, A. Bruskin, D. Jarosz, P. Friedman, C. Prives, and B. Vogelstein. 1991. Identification of p53 as a sequence-specific DNA-binding protein. Science 252: 1708-
1711.

LaFlamme, S.E., S.K. Akiyama, and K. Yamada. 1992. Regulation of fibronectin receptor distribution. I. Cell Biol. 117: 437-447.

Levine, A.J. 1993. The tumor suppressor genes. Annu. Rev. Biochem. 62: 623-651.

Lin, J.Y., J.D. Chen, B. Elenbaas, and A.J. Levine. 1994. Several hydrophobic amino acids in the p53 amino-terminal domain are required for transcriptional activation, binding to $\mathrm{mdm}-2$ and the adenovirus 5 ElB $55-\mathrm{kD}$ protein. Genes \& Dev. 8: $1235-1246$.

Lotem, J. and L. Sachs. 1993. Hematopoietic cells from mice deficient in wild-type p53 are more resistant to induction of apoptosis by some agents. Blood 82: 1092-1096.

Lowe, S.W. and H.E. Ruley. 1993. Stabilization of the p53 tumor suppressor is induced by adenovirus- $5 \mathrm{E} 1 \mathrm{~A}$ and accompanies apoptosis. Genes थ Dev. 7: 535-545.

Lowe, S.W., H.E. Ruley, T. Jacks, and D.E. Housman. 1993. p53-dependent apoptosis modulates the cytotoxicity of anticancer agents. Cell 74: 957-967.

Mack, D.H., J. Vartikar, J.M. Pipas, and L.A. Laimins. 1993. Specific repression of TATA-mediated but not initiator-mediated transcription by wild-type-p53. Nature 363: 281-283.

Marston, N.J., T. Crook, and K.H. Vousden. 1994. Interaction of p53 with MDM2 is independent of e 6 and does not mediate wild type transformation suppressor function. Oncogene 9: 2707-2716.

Michalovitz, D., O. Halevy, and M. Oren. 1990. Conditional inhibition of transformation and of cell proliferation by temperature-sensitive mutant of p53. Cell 62: 671-680.

Miyashita, T. and J.C. Reed. 1995. Tumor suppressor p53 is a direct transcriptional activator of the human bax gene. Cell 80: 293-299.

Miyashita, T., S. Krajewski, M. Krajewska, H.W. Wang, H.K. Lin, D.A. Liebermann, B. Hoffman, and J.C. Reed. 1994. Tumor suppressor p53 is a regulator of $b c l-2$ and bax gene expression in vitro and in vivo. Oncogene 9: 1799-1805.

Morgenbesser, S.D., B.O. Williams, T. Jacks, and R.A. DePinho. 1994. p53-dependent apoptosis produced by $\mathrm{Rb}$-deficiency in the developing mouse lens. Nature 371: 72-74.

Okamoto, K. and D. Beach. 1994. Cyclin G is a transcriptional target of the p53 tumor suppressor protein. EMBO $/ .13$ : 4816-4822.

Oliner, J.D., J.A. Pietenpol, S. Thiagalingam, J. Gvuris, K.W. Kinzler, and B. Vogelstein. 1993. Oncoprotein MDM2 conceals the activation domain of tumour suppressor-p53. $\mathrm{Na}$ ture 362: 857-860.

Oren, M. 1992. p53-The ultimate tumor suppressor gene. FASEB I. 6: 3169-3176.

. 1994. Relationship of p53 to the control of apoptotic cell death. Semin. Cancer Biol. 5: 305.1-305.7.

Ory, K., Y. Legros, C. Auguin, and T. Soussi. 1994. Analysis of the most representative tumor-derived p 53 mutants reveals that changes in protein conformation are not correlated with loss of transactivation or inhibition of cell proliferation. EMBO I. 13: 3496-3504.

Pan, H. and A.E. Griep. 1994. Altered cell cycle regulation in the lens of HPV-16 E6 or E7 transgenic mice: Implications for tumor suppressor gene function in development. Genes \& Dev. 8: 1285-1299.

Pavletich, N.P., K.A. Chambers, and C.O. Pabo. 1993. The DNAbinding domain of p53 contains the 4 conserved regions and the major mutation hot spots. Genes \& Dev. 7: 2556-2564.

Pietenpol, J.A., T. Tokino, S. Thiagalingam, W.S. El-Deiry, K.W. Kinzler, and B. Vogelstein. 1994. Sequence-specific transcriptional activation is essential for growth suppression by 
p53. Proc. Natl. Acad. Sci. 91: 1998-2002.

Pinhasi-Kimhi, O., A. Michalovitz, A. Ben-Zeev, and M. Oren. 1986. Specific interaction between the p53 cellular tumour antigen and major heat shock proteins. Nature 320: 182-185.

Prives, C. 1994. How loops, beta sheets, and alpha helices help us to understand p53. Cell 78: 543-546.

Qin, X.-Q., D.M. Livingston, W.J. Kaelin, and P.D. Adams. 1994. Deregulated transcription factor E2F-1 expression leads to S-phase entry and p53-mediated apoptosis. Proc. Natl. Acad. Sci. 91: 10918-10922.

Ramqvist, T., K.P. Magnusson, Y.S. Wang, L. Szekely, G. Klein, and K.G. Wiman. 1993. Wild-type p53 induced apoptosis in a Burkitt lymphoma (BL) line that carries mutant p53. Oncogene 8: 1495-1500.

Reed, M., Y. Wang, G. Mayr, M.E. Enderson, J.F. Schwedes, and P. Tegtmeyer. 1993. p53 domains: Suppression, transformation, and transactivation. Gene Exp. 3: 95-106.

Ryan, J.J., R. Danish, C.A. Gottlieb, and M.F. Clarke. 1993. Cell cycle analysis of p53-induced cell death in murine erythroleukemia cells. Mol. Cell Biol. 13: 711-719.

Sabbatini, P., S.K. Chiou, L. Rao, and E. White. 1995. Modulation of p53-mediated transcriptional repression and apoptosis by the adenovirus E1B 19K protein. Mol. Cell Biol. 15: 1060-1070.

Santhanam, U., A. Ray, and P.B. Sehgal. 1991. Repression of the interleukin 6 gene promoter by $\mathrm{p} 53$ and the retinoblastoma susceptibility gene product. Proc. Natl. Acad. Sci. 88: 76057609.

Selvakumaran, M., H.K. Lin, T. Miyashita, H.G. Wang, S. Krajewski, J.C. Reed, B. Hoffman, and D. Liebermann. 1994. Immediate early up-regulation of bax expression by p53 but not TGF beta 1: A paradigm for distinct apoptotic pathways. Oncogene 9: 1791-1798.

Shaulian, E., A. Zauberman, D. Ginsberg, and M. Oren. 1992. Identification of a minimal transforming domain of p53: Negative dominance through abrogation of sequence-specific DNA binding. Mol. Cell Biol. 12: 5581-5592.

Shaulian, E., A. Zauberman, J. Milner, E.A. Davies, and M. Oren. 1993. Tight DNA binding and oligomerization are dispensable for the ability of $\mathrm{p} 53$ to transactivate target genes and suppress transformation. EMBO J. 12: 2789-2797.

Shaulian, E., I. Haviv, Y. Shaul, and M. Oren. 1995. Transcriptional repression by the C-terminal domain of p53. Oncogene 10: 671-680.

Shaulsky, G., N. Goldfinger, A. Ben-Ze'ev, and V. Rotter. 1990. Nuclear accumulation of p53 protein is mediated by several nuclear localization signals and plays a role in tumorigenesis. Mol. Cell Biol. 10: 6565-6577.

Shaw, P., R. Bovey, S. Tardy, R. Sahli, B. Sordat, and J. Costa. 1992. Induction of apoptosis by wild-type p53 in a human colon tumor-derived cell line. Proc. Natl. Acad. Sci. 89: 4495-4499.

Shen, Y.Q. and T. Shenk. 1994. Relief of p53-mediated transcriptional repression by the adenovirus E1B $19-\mathrm{kDa}$ protein or the cellular bcl-2 protein. Proc. Nat1. Acad. Sci.. 91: 8940-8944.

Slebos, R.J.C., M.H. Lee, B.S. Plunkett, T.D. Kessis, B.O. Williams, T. Jacks, L. Hedrick, M.B. Kastan, and K.R. Cho. 1994. p53-dependent G1 arrest involves pRB-related proteins and is disrupted by the human papillomavirus 16 E7 oncoprotein. Proc. Natl. Acad. Sci. 91: 5320-5324.

Smith, M.L., I.-T. Chen, Q. Zhan, I. Bae, C.-Y. Chen, T.M. Gilmer, M.B. Kastan, P.M. O'Connor, and A.J. Fornace, Jr. 1994. Interaction of the p53-regulated protein Gadd45 with proliferating cell nuclear antigen. Science 266: 1376-1380.

Soussi, T., C.C. de Fromentel, and P. May. 1990. Structural aspects of the p53 protein in relation to gene evolution. Oncogene 5: 945-952.
Sturzbecher, H.W., R. Brain, C. Addison, K. Rudge, M. Remm, M. Grimaldi, E. Keenan, and J.R. Jenkins. 1992. A C-terminal alpha-helix plus basic region motif is the major structural determinant of p53 tetramerization. Oncogene 7: 1513-1523.

Subler, M.A., D.W. Martin, and S. Deb. 1992. Inhibition of viral and cellular promoters by human wild-type p53. I. Virol. 66: $4757-4762$.

Symonds, H., L. Krall, L. Remington, M. Saenz-Robles, S. Lowe, T. Jacks, and T. Van Dyke. 1994. p53-dependent apoptosis suppresses tumor growth and progression in vivo. Cell 78: 703-711.

Thut, C.J., J.L. Chen, R. Klemm, and R. Tjian. 1995. p53 transcriptional activation mediated by coactivators $\mathrm{TAF}_{\mathrm{II}} 40$ and $\mathrm{TAF}_{\mathrm{II}}$ 60. Science 267: 100-104.

Unger, T., M.M. Nau, S. Segal, and J.D. Minna. 1992. p53-A transdominant regulator of transcription whose function is ablated by mutations occurring in human cancer. EMBO $J$. 11: 1383-1390.

Vogelstein, B. and K.W. Kinzler. 1992. p53 function and dysfunction. Cell 70: 523-526.

Waga, S., G.J. Hannon, D. Beach, and B. Stillman. 1994. The p21 inhibitor of cyclin-dependent kinases controls DNA replication by interaction with PCNA. Nature 369: 574-578.

Wagner, A.J., J.M. Kokontis, and N. Hay. 1994. Myc-mediated apoptosis requires wild-type p53 in a manner independent of cell cycle arrest and the ability of p53 to induce p $21^{\text {waf } 1 / \text { cip } 1}$ Genes \& Dev. 8: 2817-2830.

Wang, Y.S., L. Szekely, I. Okan, G. Klein, and K.G. Wiman. 1993. Wild-type p53-triggered apoptosis is inhibited by bcl-2 in a v-myc-induced T-cell lymphoma line. Oncogene 8: 3427-3431.

White, A.E., E.M. Livanos, and T.D. Tlsty. 1994. Differential disruption of genomic integrity and cell cycle regulation in normal human fibroblasts by the HPV oncoproteins. Genes (4) Dev. 8: 666-677.

Wu, X. and A.J. Levine. 1994. p53 and E2F-1 cooperate to mediate apoptosis. Proc. Nat1. Acad. Sci.. 91: 3602-3606.

Wu, X., J.H. Bayle, D. Olson, and A.J. Levine. 1993. The p53mdm-2 autoregulatory feedback loop. Genes \& Dev. 7: 1126-1132.

Xiong, Y., G.J. Hannon, H. Zhang, D. Casso, R. Kobayashi, and D. Beach. 1993. p21 is a universal inhibitor of cyclin kinases. Science 366: 701-704.

Yonish-Rouach, E., D. Resnitzky, J. Lotem, L. Sachs, A. Kimchi, and M. Oren. 1991. Wild-type p53 induces apoptosis of myeloid leukaemic cells that is inhibited by interleukin- 6 . $\mathrm{Na}$ ture 352: 345-347.

Yonish-Rouach, E., D. Ginsberg, and M. Oren. 1993. The role of tumour suppressor genes in apoptosis. In Programmed cell death (ed. M. Levin and D. Watters), pp. 187-202. Harwood Academic Publishers, Chur, Switzerland.

Yonish-Rouach, E., J. Borde, M. Gotteland, Z. Mishal, A. Viron, and E. May. 1994. Induction of apoptosis by transiently transfected metabolically stable wt p53 in transformed cell lines. Cell Death Differ. 1: 39-47.

Zauberman, A., A. Lupo, and M. Oren. 1995. Identification of p53 target genes through immune selection of genomic DNA: The cyclin G gene contains two distinct $\mathrm{p} 53$ binding sites. Oncogene (in press).

Zhan, Q., S. Fan, I. Bae, C. Guillouf, D.A. Liebermann, P.M. O'Connor, and A.J. Fornace Jr. 1994. Induction of bax by genotoxic stress in human cells correlates with normal p53 status and apoptosis. Oncogene 9: 3743-3751.

Zhang, W., X.Y. Guo, G.Y. Hu, W.B. Liu, J.W. Shay, and A.B. Deisseroth. 1994. A temperature-sensitive mutant of human p53. EMBO I. 13: 2535-2544. 


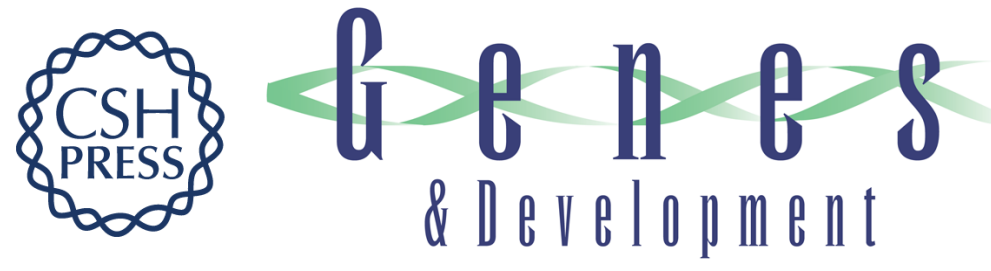

\section{Induction of apoptosis in HeLa cells by trans-activation-deficient p53.}

Y Haupt, S Rowan, E Shaulian, et al.

Genes Dev. 1995, 9:

Access the most recent version at doi:10.1101/gad.9.17.2170

$\begin{array}{ll}\text { References } & \begin{array}{l}\text { This article cites } 98 \text { articles, } 44 \text { of which can be accessed free at: } \\ \text { http://genesdev.cshlp.org/content/9/17/2170.full.html\#ref-list-1 }\end{array}\end{array}$

License

Email Alerting

Receive free email alerts when new articles cite this article - sign up in the box at the top Service right corner of the article or click here.

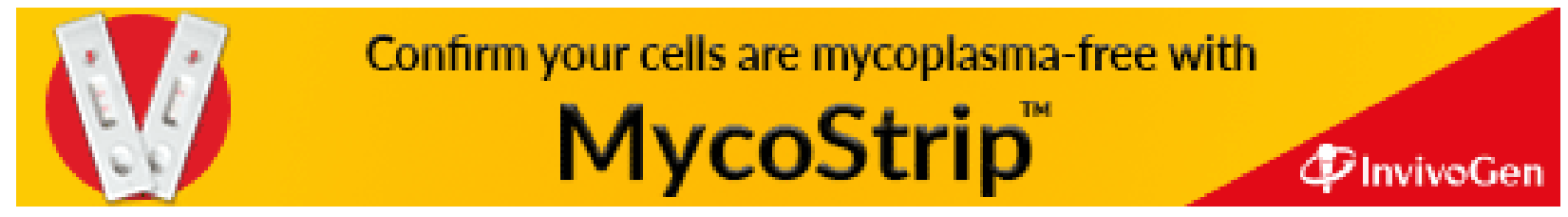

